\title{
Probing into Job Satisfaction Among Community Campus Teachers
}

\section{OPEN ACCESS}

Manuscript ID:

ASH-2021-09024316

Volume: 9

Issue: 2

Month: October

Year: 2021

P-ISSN: 2321-788X

E-ISSN: 2582-0397

Received: 10.07.2021

Accepted: 25.09.2021

Published: 01.10.2021

Citation:

Sharma, Lok Raj. "Probing into Job Satisfaction Among Community Campus Teachers." Shanlax International Journal of Arts, Sciences and Humanities, vol. 9, no. 2, 2021, pp. 1-10.

\section{DOI:}

https://doi.org/10.34293/

sijash.v9i2.4316

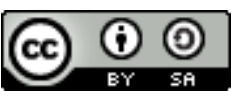

This work is licensed under a Creative Commons Attribution-ShareAlike 4.0 International License

\author{
Lok Raj Sharma \\ Associate Professor of English, Makawanpur Multiple Campus, Hetauda, Nepal \\ (D) https://orcid.org/0000-0002-5127-2810
}

\begin{abstract}
The chief objective of this article is to probe into the level of job satisfaction among community campus teachers. Job satisfaction is the state of how content persons are with their jobs. It can be appraised on the basis of their responses to their feelings, perceptions, likes and dislikes for the jobs. Divergent factors can influence the satisfaction level of the personnel in their work. A crosssectional survey design was adopted to carry out the research study. Twenty question items of five-point Likert scale type regarding the job satisfaction of the teachers were administered at two campuses situated in Dang District of Nepal in 2020. Simple random sampling technique (lottery) was used to select 52 campus teachers as respondents for the study by maintaining the confidence level (95\%) and the margin of error (5\%) from the population of 59 teachers. The collected data were statistically analyzed by using SPSS.The study revealed that the teachers were satisfied (Median =4) with their teaching profession at the respective campuses. The Mann-Whitney U test showed that the teachers of the two campuses had a similar level of job satisfaction. Similarly, there was no statistically significant difference in the job satisfaction between male teachers and female teachers.
\end{abstract}

Keywords: Community campus, Motivation, Ordinal data, Satisfaction, Teachers, Teaching.

\section{Introduction}

Teachers are the persons who are fully devoted to the field of teaching and learning activities. Teaching comes after learning, and real learning comes after teaching. People consider teachers the pillars of the nation. Teachers produce manpower that is essential to the overall development of the nation. Teachers through imparting their knowledge, skills and experiences to the students encourage and inspire them to apply their knowledge for the betterment of the nation and the well-being of the people. Teachers play a vital role in developing the knowledge and skills in the youth.

If they are satisfied with their job, they teach the students with their heart and soul. They would get interested to teach their students effectively. If they are dissatisfied, they will pretend to be teaching. Unfortunately, the Nepalese Government does not seem to give much priority to the teachers and teaching. The Government has not realized yet that teachers' job satisfaction does not only affect the teachers, but it also affects the teaching learning activities, and the society. Despite the Government's poor policy for education, every teacher must have the potential and clear intention to discharge their duty with utmost devotion to derive satisfaction from their teaching. Job satisfaction is the combination of feelings, perceptions, likes and dislikes resulting in an emotional and psychological experience at any work. Job Satisfaction is the relationship between what everyone expects and achieves.

Teaching at a campus is a respected profession. It is regarded as a fair and clean profession since there is no chance of committing corruption. The major income source is the monthly salary. 
Other regular income source may be their extra periods, tuition and coaching classes. Teachers earn money only with the sweat of their brow. Lazy and dull persons can't be teachers. The persons who do not like to keep studying can't be teachers. Teaching is a tough job that demands the teachers with the sound mind in the sound body. They must be resourceful and up-to-date. Most of the persons in Nepal do not want to be teachers in spite their respect. They like such jobs that give them chances of earning more extra money, legally or illegally, along with their handsome salaries with additional facilities. Such things make some teachers think they do not have a great job. Naturally, they remain humble and polite in our society.

There are primarily three types of campuses in Nepal. They are constituent campuses, community campuses, and private campuses. The constituent campus teachers get their salary and other facilities from the government. The community campuses are run by the community. Such campuses are non-profit making institutes. The private campuses are run by a person or a group of persons for the business point of view. The constituent campus teachers seem satisfied with their job because of job security, the private campus teachers do not seem to be satisfied because of their job insecurity, and it is not clear about the community campus teachers' job satisfaction, therefore the article writer was curious to carry out a mini-survey to examine the level of job satisfaction of the community campus teachers in Dang. Dang is a large district that covers Terai area, Valley area and the Hill area. One Community campus is situated in the valley with the hill, and another campus lies in the Terai belt.

This article is based on the cross-sectional survey research design which involves twenty Likert type question items by focusing on payment, facilities, promotional opportunity, carrier advancement, relationship with colleagues, working environment, the nature of the Campus Chief, teaching skill, performance of students, job security, public opinion on the image of campus and overall job satisfaction level with the teaching profession at the existing campuses. The data were taken at one point in time (2020) at two campuses as sections. The data were analyzed by employing descriptive statistics percent, median, and mode in SPSS. The Mann-Whitney $\mathrm{U}$ test was done to test the null hypothesis. This article is significant, because it may represents job satisfaction of all community campus teachers of Nepal.

\section{Statement of the Problem}

One of the major problems of this research study is regarding the employment of the proper statistical tools to probe the teachers' job satisfaction. Some researchers use mean and standard deviation for analysis of data, and t test and ANOVA for hypothesis test with ordinal data, whereas other researchers like to use median, mode, frequency, the Mann-Whitney U test and the Kruskal-Wallis H test with ordinal data. This researcher has used median, mode, and percent for the analysis of data, and the Mann-Whitney U test for hypothesis test. The responses in Likert scale statement items do not have absolute zero points unlike the ratio scale. They just refer to the level of satisfaction. Another problem that the researcher did face was with the construction of question items that might include all the factors that contribute to the job satisfaction of teachers on the whole.

\section{Significance of the Study}

No study has been carried out to assess the community campus teachers' job satisfaction at campuses situated in Dang district, Nepal. This research is significant because it may represent the job satisfaction level of all the community campus teachers who have been teaching in Nepal. This article might give feed back to the community campus management and administration to understand the level of satisfaction of the teachers, and might make the campus administration ponder on making the policy for increasing the level of job satisfaction of the teachers.

\section{Objectives of the research study}

The objectives of the research objectives were:

- To probe into the community campus teachers' satisfaction with their jobs.

- To find out the level of satisfaction with their jobs. 


\section{Null Hypotheses}

The null hypotheses of the research study were:

- There is no statistically significant difference in the level of job satisfaction of the teachers between two community campuses.

- There is no statistically significant difference in the level of job satisfaction between male teachers and female teachers.

\section{Delimitations of the Study}

The research was carried out under the following delimitations:

- The study was limited to the teachers of two campuses situated in Dang District.

- Only two community campuses were involved as the sample of population.

- Only 20 question items regarding the job satisfaction were constructed to elicit the data for the study.

\section{Literature Review}

Literature review encompasses views of different researchers concerning job satisfaction and some factors that affect the job satisfaction. Job satisfaction is a vital notion that is not only related to an individual but it is relevant for the society's well being in case of the teachers. Teachers with the light of their knowledge and wisdom can lead the people of the society from darkness to light. Therefore, their satisfaction is a matter of great concern. Locke (1976) defines job satisfaction as "a pleasurable or positive emotional state resulting from the appraisal of one's job or job experiences". Cormick and Tiffin (1979) view the job satisfaction as "satisfaction with one's job, which in turn is a function of the degree of need satisfaction derived from or experienced in the job". Similarly, Gilmer (1974) takes the job satisfaction as "job satisfaction or dissatisfaction is the result of various attitudes the person holds towards his job, towards the related factors and towards life in general". Similar opinion about job satisfaction is highlighted by Grant (2008) who asserts that “ job satisfaction is an evaluative judgment about the extent to which one's overall work experiences meet one's expectations or standards". The two most common definitions of job satisfaction are given by Locke (1976) who considers job satisfaction as "the pleasurable emotional state resulting from the appraisal of one's job as achieving or facilitating the achievement of one's job values", and Spector (1997) who views satisfaction as "the extent to which people like (satisfaction) or dislike (dissatisfaction) their jobs".

Every person has a different level of satisfaction. Porter and Lawler (1989) assert that "people having high self-control, responsibility and high level of challenge derive more intrinsic satisfaction from the job". Job satisfaction depends on several factors like age, education and type of work etc. Smith, Kendall and Hulin (1969) suggest five major characteristics which contribute to the job satisfaction of an employee. These are "work itself, pay package, promotional opportunities, nature of supervision and interpersonal relationship with peers". Schaffer (1953) has argued that "job satisfaction will vary directly with the extent to which those needs of an individual which can be satisfied are actually satisfied". Vroom (1964) also sees job satisfaction in terms of the degree to which a job "provides the person with positively valued outcomes". Motivation plays an important role in accomplishing a job. Grant (2008) defines intrinsic motivation as "the desire to expand effort based on interest in and enjoyment of the work itself and extrinsic motivation as the desire to expand effort to obtain outcomes external to the work itself such as rewards or recognition". Abdel-Halim (1980) views the higher order needs strength as "the extent to which the individual values the importance of higher level work outcomes". Aziri (2011) studies job satisfaction and finds that job satisfaction is under the influence of a series of factors such as "the nature of work, salary, advancement opportunities, management, work groups and work conditions". Howard and ohnson (2004), Peltzer, Shisana, Zuma, Wyak and Dirwayi (208) and Castro, Kelly and Minyi (2010) point out a lack of resources and support systems to influence job satisfaction negatively. Kalleberg (1977) identifies the return of work and the consequent value as the most important predictor of job satisfaction. She regards job satisfaction as the overall positioning of employees for the different job roles she represents. Billingsley (2004) affirms that job satisfaction can be determined by internal and external factors: 
internal factors are mainly determined by a person's motivation and can include non-material recognition of the work done; external factors include working environment, supervision and working conditions. George, Louw, and Badenhorst (2008) assert that job satisfaction in education is affected by factors such as personal experience, demographics, and personality, as well as physical, social, psychological, emotional, and economic factors. These views show that job satisfaction is a complex phenomenon.

Mueller and Kim (2008) identified two types of job satisfaction as "the overall feeling about the job, and the feelings about the aspects of the job, such as benefits, salary, position, growth opportunities, work environment, and the relationships among employees". In fact, teachers in particular have a special opportunity to develop human potential and consequently a better society". Such a sort of feeling may make the teachers satisfy with their job to some extent. All these assertions and opinions point out that job satisfaction is an intricate concept, because it is formed by varied factors.

\section{Methodology of the Study Research Design}

A cross-sectional survey design was used to carry out the study. The researcher collected data to probe the two community campus teachers' satisfaction with their job.

\section{Sampling Design and Sample Size}

Simple random sampling technique / design, especially the lottery method was used to select 52 teachers (46 male teachers and 6 female teachers) for the study according to the sample size calculator maintaining the margin of error $(5 \%)$ and the confidence level (95\%) from two community campuses in Dang District of Nepal.

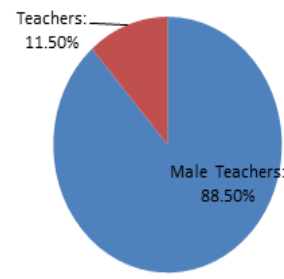

Figure 1: Percent of Male and Female Teachers in the Study

\section{Sample Size}

Twenty-nine teachers from one campus and twenty-three teachers from another campus were involved as respondents in this study. Both campuses were affiliated to Tribhuvan University Nepal and National Examinations Board (NEB). They have been running the classes of $10+2$, Bachelor and Masters in the faculty of Management, Humanities and Education.

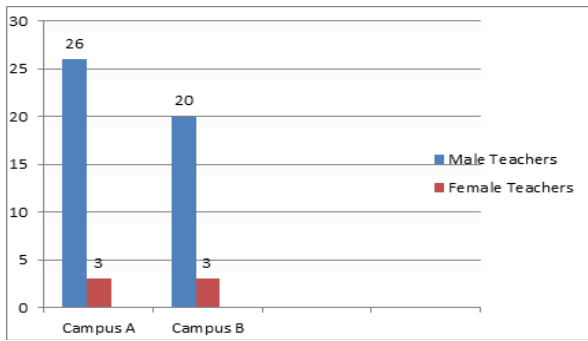

Figure 2: Number of Male and Female Teachers of Two Campuses in the Study

\section{Nature and Source of Data}

The researcher employed ordinal scale data. Teachers' satisfaction with their job was obtained through the use of five-point Likert scale question items with Strongly Satisfied (SS) $=5$, Satisfied (S) $=4$, Undecided (UD) $=3$, Dissatisfied (D) $=2$ and Strongly Dissatisfied $(\mathrm{SD})=1$. The numbers assigned to them indicated only the order of satisfaction. The primary source of data was questionnaire. The secondary source of data included books, journal articles, web-sites etc.

\section{Validity and Reliability of the Instruments}

The validity of questionnaire was conducted using Pearson Product Moment Correlations in SPSS, where the score of each item was correlated with the median score. The significant value (2-tailed) was smaller than 0.05 and the Pearson Product moment correlation count value was greater than the corresponding Pearson correlation critical value $/ \mathrm{r} />\mathrm{rc}=0.273$ of each question item. It can be concluded that each question item was valid for the research study. The Cronbach's alpha' was used to check the reliability of the survey instruments. The overall internal consistency estimated 0.965 indicates the instrument to be highly reliable in measuring the teachers' satisfaction with their job. 


\section{Analysis and Interpretation of Data}

The researcher designed a series of Likert type question items to probe the teachers' satisfaction with their job. The data being in the ordinal scale, it was appropriate to use descriptive statistics such as mode, median and percent to analyze the data; and inferential statistics the Mann-Whitney $U$ test for null hypothesis test. All the data were analyzed by using Statistical Package for Social Sciences (SPSS).

\section{Calculation of the Median and Mode}

The researcher used the following median scale to examine the level of satisfaction for analyzing the result
Table 1: Median scale and level of satisfaction

\begin{tabular}{|c|c|}
\hline Median Scale & Level of Satisfaction \\
\hline $1.0-1.49$ & Strongly Dissatisfied \\
\hline $1.5-2.49$ & Dissatisfied \\
\hline $2.5-3.49$ & Undecided \\
\hline $3.5-4.49$ & Satisfied \\
\hline $4.5-5.00$ & Strongly Satisfied \\
\hline
\end{tabular}

\section{Formation of Research Questions}

The researcher formed the satisfaction measuring question items based on the payment, additional facilities, promotional opportunities, career advancement, job security, the nature of the Campus Chief, relationship with colleagues, teaching skill and plan, students' performance, public opinion on the image of the campus, and the teaching life style.

Table 2: Teachers' Responses to the questions

\begin{tabular}{|c|c|c|c|c|}
\hline Q.N. & How satisfied are you with & Mode & Median & $\begin{array}{c}\text { Level of Satisfaction } \\
\text { Based on Median Score } \\
\end{array}$ \\
\hline 1. & ...your salary? & 4 & 4 & $\mathrm{~S}$ \\
\hline 2. & ...the allowance you get for the extra classes? & 4 & 4 & $\mathrm{~S}$ \\
\hline 3. & $\begin{array}{l}\ldots \text { the policies of your campus regarding salaries, leave } \\
\text { facilities and promotional opportunities? }\end{array}$ & 4 & 4 & $\mathrm{~S}$ \\
\hline 4. & $\begin{array}{l}\text {... your recognition and reward for your good performance } \\
\text { and accomplishments at campus? }\end{array}$ & 4 & 4 & $\mathrm{~S}$ \\
\hline 5. & $\begin{array}{l}\text {... the support of your campus to pursue your } \\
\text { professional growth? }\end{array}$ & 4 & 4 & $\mathrm{~S}$ \\
\hline 6. & $\begin{array}{l}\text {... the condition of your campus about your job } \\
\text { security? }\end{array}$ & 4 & 4 & $\mathrm{~S}$ \\
\hline 7. & $\begin{array}{l}\text {...your Campus Chief's encouragement and support to } \\
\text { develop your fullest ability? }\end{array}$ & 4 & 4 & $\mathrm{~S}$ \\
\hline 8. & $\begin{array}{l}\text {... your Campus Chief's admiration for your good } \\
\text { performance and meritorious achievements? }\end{array}$ & 4 & 4 & $\mathrm{~S}$ \\
\hline 9. & $\begin{array}{l}\text {... your campus Chief's information about your work, } \\
\text { training, responsibility and facility? }\end{array}$ & 4 & 4 & $\mathrm{~S}$ \\
\hline 10. & $\begin{array}{l}\text {... the possibilities to receive financial assistance from } \\
\text { colleagues when necessary? }\end{array}$ & 4 & 4 & $\mathrm{~S}$ \\
\hline 11. & ... the cooperation and team work of your colleagues? & 4 & 4 & $\mathrm{~S}$ \\
\hline 12. & $\begin{array}{l}\text {... The mutual cooperation and the feelings of co- } \\
\text { existence among teaching and non-teaching staff of } \\
\text { your campus? }\end{array}$ & 4 & 4 & $\mathrm{~S}$ \\
\hline 13. & ... your teaching skill? & 4 & 4 & $\mathrm{~S}$ \\
\hline 14. & $\begin{array}{l}\text {... the preparation of the teaching items for teaching } \\
\text { the students? }\end{array}$ & 4 & 4 & $\mathrm{~S}$ \\
\hline
\end{tabular}




\section{SHANLAX}

International Journal of Arts, Science and Humanities

\begin{tabular}{|c|c|c|c|c|}
\hline 15. & $\begin{array}{l}\ldots \text { your freedom for making decision to accomplish } \\
\text { your assigned work? }\end{array}$ & 4 & 4 & $\mathrm{~S}$ \\
\hline 16. & ... your students' manners and behaviours? & 4 & 4 & $\mathrm{~S}$ \\
\hline 17. & $\begin{array}{l}\text {... your students' attention to your lecture / teaching in } \\
\text { the classroom? }\end{array}$ & 4 & 4 & $\mathrm{~S}$ \\
\hline 18. & $\begin{array}{l}\text {... your students' academic performance in your } \\
\text { subjects? }\end{array}$ & 4 & 4 & $\mathrm{~S}$ \\
\hline 19. & ... the public opinion on the image of your campus? & 4 & 4 & $\mathrm{~S}$ \\
\hline 20. & $\begin{array}{l}\ldots \text { your life style regarding your teaching profession at } \\
\text { this campus? }\end{array}$ & 4 & 4 & $\mathrm{~S}$ \\
\hline \multicolumn{2}{|r|}{ Concluding Results } & 4 & 4 & Satisfied \\
\hline
\end{tabular}

This table shows that median and mode of every question item was 4 on the whole. The median score shows the mid value. The mode tells that it is the most frequently repeated score in the distribution. The median and mode values in this table indicate the teachers' satisfaction level with their job.

\section{Percent}

Percent is also a useful tool to discern the level of satisfaction. If the percents of "Agree" and / or "Strongly Agree" are greater than those of "Strongly Disagree", "Disagree" and "Undecided", they suggest the teachers' satisfaction with their job.

Table 3: Number and Percent of Teachers Responding to Each Question Item

\begin{tabular}{|c|c|c|c|c|c|c|}
\hline Q.N. & Strongly Dissatisfied & Dissatisfied & Undecided & Satisfied & Strongly Satisfied & Total \\
\hline 1. & $4(7.7 \%)$ & $5(9.6 \%)$ & $5(9.6 \%)$ & $22(42.3 \%)$ & $11(21.2 \%)$ & $52(100 \%)$ \\
\hline 2. & $6(11.5 \%)$ & $6(11.5 \%)$ & $6(11.5 \%)$ & $25(48.1 \%)$ & $9(17.3 \%)$ & $52(100 \%)$ \\
\hline 3. & $\ldots$. & $5(9.6 \%)$ & $3(5.8 \%)$ & $30(57.7 \%)$ & $14(26.9 \%)$ & $52(100 \%)$ \\
\hline 4. & $8(15.4 \%)$ & $6(11.5 \%)$ & $6(11.5 \%)$ & $26(50 \%)$ & $6(11.5 \%)$ & $52(100 \%)$ \\
\hline 5. & $4(7.7 \%)$ & $10(19.2 \%)$ & $2(3.8 \%)$ & $21(40.4 \%)$ & $15(28.8 \%)$ & $52(100 \%)$ \\
\hline 6. & $5(9.6 \%)$ & $3(5.8 \%)$ & $8(15.4 \%)$ & $22(42.3 \%)$ & $14(26.9 \%)$ & $52(100 \%)$ \\
\hline 7. & $3(5.8 \%)$ & $6(11.5 \%)$ & $6(11.5 \%)$ & $21(40.4 \%)$ & $16(30.8 \%)$ & $52(100 \%)$ \\
\hline 8. & $3(5.8 \%)$ & $8(15.4 \%)$ & $6(11.5 \%)$ & $21(40.4 \%)$ & $14(26.9 \%)$ & $52(100 \%)$ \\
\hline 9. & $4(7.7 \%)$ & $7(13.5 \%)$ & $5(9.6 \%)$ & $25(48.1 \%)$ & $11(21.2 \%)$ & $52(100 \%)$ \\
\hline 10. & $10(19.2 \%)$ & $7(13.5 \%)$ & $6(11.5 \%)$ & $16(30.8 \%)$ & $13(25.0 \%)$ & $52(100 \%)$ \\
\hline 11. & $5(9.6 \%)$ & $7(13.5 \%)$ & $6(11.5 \%)$ & $18(34.6 \%)$ & $16(30.8 \%)$ & $52(100 \%)$ \\
\hline 12. & $5(9.6 \%)$ & $7(13.5 \%)$ & $7(13.5 \%)$ & $21(40.4 \%)$ & $12(23.1 \%)$ & $52(100 \%)$ \\
\hline 13. & $\ldots$. & $8(15.4 \%)$ & $2(3.85)$ & $26(50.0 \%)$ & $16(30.8 \%)$ & $52(100 \%)$ \\
\hline 14. & $7(13.5 \%)$ & $6(11.5 \%)$ & $5(9.6 \%)$ & $25(48.1 \%)$ & $9(17.3 \%)$ & $52(100 \%)$ \\
\hline 15. & $5(9.6 \%)$ & $12(23.1 \%)$ & $1(1.9 \%)$ & $21(40.4 \%)$ & $13(25.0 \%)$ & $52(100 \%)$ \\
\hline 16. & $5(9.6 \%)$ & $3(5.8 \%)$ & $9(17.3 \%)$ & $20(38.5 \%)$ & $15(28.8 \%)$ & $52(100 \%)$ \\
\hline 17. & $3(5.8 \%)$ & $6(11.5 \%)$ & $6(11.5 \%)$ & $20(38.5 \%)$ & $17(32.7 \%)$ & $52(100 \%)$ \\
\hline 18. & $3(5.8 \%)$ & $9(17.3 \%)$ & $5(9.6 \%)$ & $21(40.4 \%)$ & $14(26.9 \%)$ & $52(100 \%)$ \\
\hline 19. & $3(5.8 \%)$ & $7(13.5 \%)$ & $5(9.6 \%)$ & $25(48.1 \%)$ & $12(23.1 \%)$ & $52(100 \%)$ \\
\hline 20. & $6(11.5 \%)$ & $8(15.4 \%)$ & $5(9.6 \%)$ & $24(46.2 \%)$ & $9(17.3 \%)$ & $52(100 \%)$ \\
\hline
\end{tabular}

Regarding the question No. 1, out of 52 teachers, their salary, $5(9.6 \%)$ teachers were dissatisfied, $4(7.7 \%)$ teachers were strongly dissatisfied with $5(9.6 \%)$ teachers were undecided, $22(42.3 \%)$ 
teachers were satisfied, and $11(21.2 \%)$ teachers were strongly satisfied with their salary. Almost similar level of satisfaction can be observed regarding the other question items. This table shows that shadowed percents of "satisfied" were greater than those of "Strongly Dissatisfied", "Dissatisfied" and "Undecided" in each question item. This indicates the teachers' satisfaction with their job.

\section{Inferential Analysis of Data and Results}

This research study adopted Independent Samples Mann-Whitney U Test for null hypothesis test.

\section{The Mann-Whitney U Test}

The researcher used the Mann-Whitney U test to determine if there were statistically significant differences between two groups of an independent variable on an ordinal dependent variable. In this study, teachers teaching at two different campuses stood for two independent samples or variables or groups; whereas the median score functioned as a dependent variable.

\section{Table 4: Hypothesis Test Summary}

\begin{tabular}{|c|c|c|c|}
\hline Null Hypothesis & Test & Sig. & Decision \\
\hline The distribution & Independent & & Retain \\
of median is & Samples & $\cdot$ & the null \\
similar across & Mann- & 818 & hypothesis \\
categories of & Whitney U & & \\
campus. & Test & & \\
\hline
\end{tabular}

\section{Asymptotic Significances are Displayed The Significance Level is .05}

This table shows that the probability figure marked as Sig (2-tailed) in the table was .818 which was larger than 0.05 . It implies that the teachers of both campuses had the similar level of satisfaction regarding their job at their respective campuses. In other words, it accepts the null hypothesis that there is no statistically significant difference in the satisfaction level of the teachers of two community campuses.

\section{Asymptotic Significances are Displayed The significance Level is .05.}

This table shows that the probability figure marked as Sig (2-tailed) in the table was .510 which was larger than 0.05 . It implies that the male and female teachers had the similar level of satisfaction regarding their job at their respective campuses. In other words, it accepts the null hypothesis that there is no statistically significant difference in the satisfaction level of the male and female teachers.

Table 5: Hypothesis Test Summary

\begin{tabular}{|c|c|c|c|}
\hline $\begin{array}{c}\text { Null } \\
\text { Hypothesis }\end{array}$ & Test & Sig. & Decision \\
\hline $\begin{array}{c}\text { The } \\
\text { distribution } \\
\text { of median is } \\
\text { similar across } \\
\text { categories of } \\
\text { sex. }\end{array}$ & $\begin{array}{c}\text { Samples Mann- } \\
\text { Whitney U Test }\end{array}$ & .510 & $\begin{array}{c}\text { Retain } \\
\text { the null } \\
\text { hypothesis }\end{array}$ \\
\hline
\end{tabular}

\section{Results and Discussion}

The median and mode score of all question items was 4. The percents of "Satisfied" of question items were higher than those of "Undecided", "Dissatisfied" and "Strongly Dissatisfied". All these descriptive statistics show the teachers' satisfaction with their job. The Mann- Whitney U Test shows that the distribution of the median score regarding their satisfaction was the similar across categories of campus (Sig. $=0.818$ ) and categories of sex (Sig. 0.510 .

The research study conducted by Ghazi, Shahzad, Shahzada and Gillani (2011) found ability utilization, creativity, social service, recognition, security, supervision human relation, independence, achievement, authority, and responsibility to play a prominent role to satisfy the personnel in their work. The head teachers were discerned to be "Very Satisfied" with moral values and activity dimensions of their job. The research study carried out by Strydom, Nortje, Beukes, Esterhuyse and Westhuizen (2012) found differences in the levels of job satisfaction between different races, but not between genders. Shabbir, Ahmed, Lawler and Shahbaz (2011) in their research study showed that job satisfaction was highly dependent upon factors like pay and benefits, relationship with co-workers and working conditions.

A research study conducted by Perie and Baker (1997) on job satisfaction with the sample size of 
36,000 teachers of America selected the simple random sampling. They implemented the crosssectional research design gathered data through structured questionnaire. Their research depicted that female teachers had higher levels of job satisfaction (37\%) than male teachers (28\%) and that teachers' job satisfaction showed weak correlations with salary and benefits.

Sharma and Jyoti (2009) carried out a research study on job satisfaction with the sample size of 120 teachers of university of Jammu, India selected through the simple random sampling technique. They followed the evaluative cum diagnostic research design, and collected data through the structured questionnaire. Their research study showed that satisfaction level increased with an increase in the level of education. The score for degree of JS enjoyed by teachers is 3.74 , which is above the average on five point scale. Gender wise analysis of job satisfaction revealed that the female teachers were more satisfied $($ Mean=3.88) than the male teachers (Mean=3.65).

A research study by Muindi (2011) on job satisfaction with the sample size of 56 college teachers of University of Nairobi implemented the cross-sectional research design with structured questionnaire to garner the data. His study revealed that there was a significantly strong positive correlation between job satisfaction and participation in decision-making $(\mathrm{r}=0.888)$.

Bholane and Suryawanshi (2015) in their research study on job satisfaction with the sample size of 274 teachers of university in Maharashtra State applied the cross-sectional research design with structured questionnaire to elicit data. Their study revealed that University teachers were most satisfied with the nature of their work and least satisfied with operating procedures. Majority of the university teachers had moderate job satisfaction. There was no significant difference in the level of job satisfaction of university teachers based on gender (0.126). There was significant difference in the level of job satisfaction of university teachers based on educational level. (0.004).

A research study accomplished by Shafi (2016) on job satisfaction with the sample size of 213 college teachers selected randomly of Colleges of Hyderabad, Pakistan by using the descriptive research design. He collected data through structured questionnaire and face to face interviews. His research showed that due to stumpy salary and lack of various facilities in colleges, $52.38 \%$ of teachers were dissatisfied, whereas only $29.78 \%$ senior teachers were found satisfied with their jobs.

Tomar and Kapri (2019) conducted a research study on job satisfaction with the sample size of 200 college teachers randomly selected in Haryana State by executing the descriptive survey design. They collected data through structured questionnaire. Their research study confirmed that the job satisfaction of male teachers of self-financed teacher education colleges was less than the job satisfaction of female teachers of self-financed teacher education colleges.

Most of the research studies carried out by previous researchers on job satisfaction indicated that female teachers had a higher level of job satisfaction than that of the male teachers; however my research study revealed that the female and male teachers had the similar level of job satisfaction. The difference in the findings might be due to different contexts. In fact, there are various factors that determine the job satisfaction. The common factors are: salary, organizational management, nature of supervision, promotional opportunities, career advancement, relationship with co-workers/ colleagues, working condition, benefits, position or responsibility, age, education, job security and social respect. All the teachers do not have the same notion of satisfaction about their job. Satisfaction level towards each and every factor differs from person to person. It might depend on personal instinct, family background, academic qualification, ambition, willingness and so on.

\section{Conclusions}

Satisfaction is contentment that is determined by divergent factors. Some factors are basic, whereas some factors are additional. Community campuses generally lie between the constituent campuses and the private campuses in the matters of job security and other facilities. The research study carried out in two community campuses situated in Dang shows that the teachers were satisfied with their jobs. Median score, mode score, and percents of satisfaction level confirm this conclusion. The Mann- 
Whitney U Test indicates that there is no statistically significant difference in the job satisfaction of two community campus teachers and between two sexes of the teachers. Literature review findings reveal that job satisfaction is a matter of personal attitudes and preferences being born from diverse factors.

\section{Acknowledgements}

I would also like to thank the Campus Chiefs and the teachers of two campuses of Dang for their cooperation and responses to the questions earnestly. My thankfulness goes to Amar Sharma for his active support in collecting data for the study.

\section{References}

Abdel-Halim, Ahmed A. "Effects of Higher Order Need Strength on the Job PerformanceJob Satisfaction Relationship." Personnel Psychology, vol. 33, no. 2, 1980, pp. 335-347.

Aziri, Brikend. "Job Satisfaction, A Literature Review." Management Research and Practice, vol. 3, no. 4, 2011, pp. 77-86.

Bholane, Kishor P., and J.R. Suryawanshi. "A Study of Job Satisfaction of University Teachers in Maharashtra State." Management Today, vol. 5, no. 4, 2015, pp. 192-195.

Billingsley, Bonnie. "Special Education Teacher Retention and Attrition: A Critical Analysis of the Research Literature." The Journal of Special Education, vol. 38, 2004, pp. 39-55.

Castro, Antonio J., et al. "Resilience Strategies for New Teachers in High-Need Areas." Teaching and Teacher Education, vol. 26, no. 3, 2010, pp. 622-629.

George, Evy, et al. "Job Satisfaction among Urban Secondary School Teachers in Namibia." South African Journal of Education, vol. 28, 2008, pp. 135-154.

Ghazi, Safdar Rehman, et al. "Job Satisfaction of Head Teachers for the Selected Twenty Dimensions of Job." International Journal of Academic Research, vol. 3, no. 1, 2011, pp. 651-654.

Gilmer, Beverly. Industrial Psychology. McGraw Hill Book Company, 1974.

Grant, Adam M. "The Significance of Task Significance: Job Performance, Effects,
Relational Mechanisms and Boundary Conditions." Journal of Applied Psychology, vol. 93, no. 1, 2008, pp. 108-124.

Howard, Sue, and Bruce Johnson. "Resilient Teachers: Resisting Stress and Burnout." Social Psychology of Education, vol. 7, 2004, pp. 399-420.

Kalleberg, Arne. "Work Values and Job Rewards: A Theory of Job Satisfaction." American Sociological Review, vol. 42, 1977, pp. 124143.

Lawler, Edward E., and Lyman W. Porter. "The Effect of Performance on Job Satisfaction." Industrial Relations, vol. 7, no. 1, 1989, pp. 20-28.

Locke, Edwin. "The Nature and Causes of Job Satisfaction." Handbook of Industrial and Organizational Psychology, edited by M. Dunnette, 1976.

Mueller, Charles, and Sang-Wook Kim. "The Contented Female Worker: Still a Paradox?" Justice, edited by K.A. Hegtvedt, and J. ClayWarner, Emerald Group Publishing Limited, 2008. pp. 117-149.

Muindi, Florence. "The Relationship between Participation in Decision Making and Job Satisfaction among Academic Staff in the School of Business, University of Nairobi." Journal of Human Resources Management Research, vol. 1, 2011.

Peltzer, Karl, et al. "Job Stress, Job Satisfaction and Stress-Related Illnesses among South African Educators." Stress and Health, vol. 25, 2009, pp. 247-257.

Perie, Marianne, and David Baker. Job Satisfaction among America's Teachers: Effects of Workplace Conditions, Background Characteristics, and Teacher Compensation. US Department of Education, 1977.

Schaffer, Robert. "Job Satisfaction as Related to Need Satisfaction in Work." Psychological Monographs, vol. 67, no. 14, 1953.

Shabbir, Muhammad Shabhaz, et al. "Affect of Working Environment on Job Satisfaction in Pakistan." World Review of Entrepreneurship, Management and Sustainable Development, vol. 7, no. 1, 2011, pp. 52-61. 
Shafi, Mohammad. "Job Satisfaction in College

Teachers: A Survey Based Study of Government Colleges of Hyderabad, Pakistan." Journal of Hotel \& Business Management, vol. 5, 2016.

Sharma, Ramji Dass, and Jeevan Jyoti. "Job Satisfaction of University Teachers: An Empirical Study." Journal of Services Research, vol. 9, no. 2, 2009, pp. 53-80.

Smith, Patricia Cain, et al. The Measurement of Satisfaction in Work and Retirement; A Strategy for the Study of Attitudes. Rand Mcnally, 1969.

Spector, Paul. Job Satisfaction: Application, Assessment, Causes, and Consequences.
Sage, 1997.

Strydom, Louise, et al. "Job Satisfaction amongst Teachers at Special Needs Schools." South African Journal of Education, vol. 32, 2012, pp. 255-266.

Tiffin, Joseph, and Earnest James Cormick. Industrial Psychology. Prentice Hall, 1979.

Tomar, Laxmi Singh, and Umesh Chandra Kapril. "A Comparative Study of Job Satisfaction of Teachers Working in Self-Financed Teacher Education Colleges." IJARIIE, vol. 5, no. 1, 2019, pp. 246-255.

Vroom, Victor H. Work and Motivation. John Wiley and Sons, 1965.

\section{Authors Details}

Lok Raj Sharma, Associate Professor of English, Makawanpur Multiple Campus, Hetauda, Nepal,

Email ID:lokraj043@gmail.com 